\title{
The Impact of Working Capital Management on Profitability: Evidence from the Listed Retail Stores in Botswana
}

\author{
Sathyamoorthi C.R. ${ }^{1}$, Mogotsinyana Mapharing ${ }^{1}$, Popo Selinkie ${ }^{1}$ \\ ${ }^{1}$ Faculty of Business, University of Botswana, Gaborone, Botswana \\ Correspondence: C.R. Sathyamoorthi, Faculty of Business, University of Botswana, P.O.Box 70430, Gaborone, \\ Botswana.E-mail: sathyamo@mopipi.ub.bw; sathyamcr@gmail.com
}

Received: December 15, 2017

Accepted: January 18, 2018

Available online: January 24, 2018

doi:10.11114/afa.v4i1.2949

URL: https://doi.org/10.11114/afa.v4i1.2949

\begin{abstract}
This study focused on the effect of working capital management on the profitability of the listed retail stores in Botswana Stock Exchange for the period 2012-2016. Financial statements of the listed Retail Stores were used as the main source of data. Return on Assets was used as the dependent variable to measure profitability and the components to measure working capital management comprised of Average Collection Period, Inventory Conversion Period, Average Payment Period, Cash Conversion Cycle, Debt, Current and Quick Ratios. Correlation analysis revealed that a few variables were significantly correlated with each other. Average Payment Period and Inventory Conversion Period were found to be positively and significantly correlated and Cash Conversion Cycle was significantly and positively correlated with Inventory Conversion Period.The regression results showed that only three variables out of the seven independent variables were statistically significant, namely Average Payment Period, Current Ratio and Quick Ratio. The remaining four variables were found to be statistically insignificant. The above findings have implications for the management of the listed retail store in Botswana.
\end{abstract}

Keywords: Botswana, retail stores, working capital management components, profitability, return on assets

\section{Introduction}

Working capital is considered as the life blood of business and signifies the funds required for the day-to-day running of a firm (Abosede \& Lugman, 2014). Working capital can be conceptualized as Gross Working Capital and Net Working Capital. The Gross Working Capital is described as the total value of current assets whereas Net Working Capital is seen as the difference between Current Assets and Current Liabilities. Current assets include accounts receivable, inventory, cash and cash equivalents. Current liabilities are made of accounts payable and other short term obligations.

Working capital management deals with management of current assets and current liabilities and monitoring the inter-relationship between them. It aims to manage both current assets and current liabilities in such a way that a satisfactory level is maintained. Poor management of working capital may lead to business collapse resulting in insolvency. For a business to succeed, it is, therefore, imperative that the working capital is managed efficiently. Azeez, Abubakar, and Olamide (2016), highlights the importance of managing short-term assets and liabilities to ensure sound financial health for all organizations and points to the fact that the investment in working capital are generally higher in proportion to the total assets employed, and this scenario demands serious examination of working capital management.

The importance of working capital management as an essential component of financial management originates from the fact that investment in current asset constitutes a significant part of total investment of a business enterprise. Working capital management comprises management of current assets and current liabilities and good working capital management ensures a satisfactory level of working capital at all times (Kumari \& Anthuvan, 2017). Windaus (2014), states that working capital gives a clear indication of how well a business is managed as it is a reliable indicator of good management and underscores that top working capital performers have outperformed across all indicators. According to Windaus (2014), only 9\% of companies around the globe manage to improve working capital consistently over multiple years.

Working capital management has become an important component of financial management in an organization on account of its impact on profitability, risk and consequently on its value (Ebenezer \& Asiedu, 2013). According to Nandom, Mubarik and Abdul-Aziz (2017), one of the critical constituents of financial management is working capital 
management which has a direct impact on the financial performance of an organization. Iqbal, Khan, Shah and Raza (2016), highlight the importance of investment in current assets as essential to ensure timely delivery of goods and services to firms' customers and underscores the fact that effective management will result in favourable impact on profitability. According to Rehman, Khan, Muhammad, Iqbal and Khan (2016) working capital management is an important element for a business enterprise, and research has revealed that it has a positive association with the firm profitability. Temtime (2016) highlights that every business enterprise should try to optimize its working capital and is seen as a tool to balance liquidity and profitability.

\subsection{Significance of the Study}

This study focused on the effect of working capital management on the financial performance of listed retail stores in Botswana. Three listed companies in the retail sector were considered for the study and covered a 5-year period from 2012 to 2016. Retail sector constitutes an important constituent of a country's economy. It plays a significant role in job creation. The study looked at important components of working capital management, namely, average collection period, inventory conversion period, average payment period, cash conversion cycle, debt, current and quick ratios and tested as to how they affect the profitability of the selected retail enterprises. The study will benefit a number of stakeholders, viz. creditors, shareholders and management of the selected organizations. The creditors will be better placed to know whether the organization has adequate funds to pay them off on time. A good credit history will always motivate easy approvals of loans by lending institutions. The management of the selected enterprises will have a better understanding of the firms' current working capital management practices and then work around those strategies and policies that would enhance firms' financial performance. To the shareholders, the study will provide insight on the importance of effective working management as a critical component for profit generation. In the academic arena, the study will be seen as a contribution to the existing body of knowledge by presenting one of the latest findings on the topic, working capital management and its impact on the financial performance of business organizations.

\subsection{Statement of the Problem}

Financial management practices do provide a sound and effective framework for management of assets. It has been observed that investment in fixed asset has been receiving more emphasis and attention in both management area and research. On the other hand effective working capital management, which has been receiving little attention from researchers, will yield more significant results and for these reasons demands more serious attention from researchers and management.

A firm's prime objective is profit generation and maximization that will result in business growth. One way of achieving this is through efficient management of working capital. The major challenge that management faces today is to strike a balance between liquidity and profitability. If profit maximization is targeted ignoring liquidity level, the company may face financial threat leading to potential bankruptcy. On the other hand, a conservative approach to liquidity may result in locking up too much of funds, leading to low profit generation. Firms have different collection and settlement periods and they have to come up with models that will focus on critical areas that would keep their working capital components at optimum level without compromising on profit maximization. The lack of understanding about the impact of working capital on profitability, the lack of clarity on its determinants and the inability of management to plan and control its components may lead to insolvency and bankruptcy (Gill, 2011).

Windaus (2017) analysed the financial performance of the largest global listed companies in the last 5 years and noted that there was deterioration in the Return on Capital Employed of global listed companies. This could be due to dramatic increase in leverage and suggested that improved working capital management could be the solution to the problem. He also highlighted a reduction in investment in the last 5 year period among global listed companies, and a way of enhancing investment would be improved working capital management.

It is therefore, established that sound working capital management is the panacea to worsening financial performance of business enterprises. The problem that most firms currently face is how to encourage their managers to pay more attention to the management of working capital to bring in a positive impact on the financial performance of the business. In this context, a study on the impact of working capital management on the profitability of selected listed retail businesses in Botswana will be found relevant. In addition, research indicates that very few studies have been carried out in Botswana on the relationship between working capital management and profitability. The study will fill in the research gap that currently exists on this topic.

\subsection{Objectives of the Study}

The main purpose of the study is to explore the effect of working capital management on the profitability of the listed retail stores in Botswana. 


\subsection{Hypotheses of the Study}

A hypothesis is a tentative statement that predicts the relationship between two or more variables (Azeez, 2015). The null hypothesis $\left(\mathrm{H}_{0}\right)$ for the study is that there is no statistically significant relationship between working capital management and profitability of listed retail stores in Botswana.

Working capital management components for the study include average collection period, inventory conversion period, average payment period, cash conversion cycle, debt ratio, current ratio and quick ratio. Return on assets is used to measure profitability.

\subsection{Literature Review}

The impact of working management on the financial performance of listed companies in various sectors has been assessed by academicians and researchers at various times. Search for prior studies on the impact of working capital management on profitability of retail stores indicates that very few studies have so far been carried out on this topic. The review of literature that follows captures the findings of those limited studies as well as in other areas of trade so as to provide a broader perspective of the concept. A review of those studies is presented below:

The review is grouped into two sections to capture studies that used Return on Total Assets to measure profitability and studies that focused on other units of performance measurements.

\subsubsection{Return on Total Assets as a Measure of Profitability}

Padachi (2006) looked at the trends in working capital management and its impact on the performance of a selected sample of 58 Mauritian Small Manufacturing firms for the period 1998-2003. The results revealed that high investment in inventories and receivables were associated with lower profitability. The findings also disclosed increasing trend in the short-term component of working capital financing.

A study by Saghir, Hashmi, and Hussain, (2011) on the relationship between profitability and working capital management conducted among a sample of 60 textile companies listed in Karachi Stock Exchange for the period 2001-2006, showed a negatively significant relationship between return on assets (as a measure of profitability) and cash conversion cycle. It was also noted that profits could be maximised by proper management of cash conversion cycle.

A negative relationship was detected between profitability and number of day's accounts receivable and cash conversion cycle and a positive relationship between profitability and number of days of inventory and number of day's payable in the study by Makori and Jagongo (2013) on the listed manufacturing and construction firms in Kenya for the period 2003-2012. Also, a significant relationship was found between profitability and financial leverage, sales growth, current ratio and firm size.

Another research by Agha, (2014) on the impact of working capital management on profitability in a listed pharmaceutical company in Karachi Stock Exchange, Pakistan for the period 1996-2011 revealed that there was significant impact of working capital management on the profitability of the company, measured by return on assets. The independent variables consisted of accounts receivable turnover, creditors' turnover, inventory turnover and current ratio.

A study on the relationship between working capital management on profitability among 50 retail stores in Kenya by Odhiambo (2014) revealed a positive relationship between inventory turnover and profitability (return on assets); a negative association between average collection period and return on assets; a significant positive relationship between average payment period and return on assets and a positive relationship between debt ratio and profitability.

An investigation by Azeez (2015) on relationship between working capital management and profitability among the listed Nigerian manufacturing firms indicated that profit was significantly affected by inventory conversion period, but negatively and significantly influenced by cash conversion cycle.

Another investigation by Temtime (2016) on the relationship between working capital management policies and profitability of 176 publically traded small U.S. manufacturing companies was carried out for the period 2004-2013. The overall conclusion from the study was that accounts receivable period, accounts payable period, working capital investment policy, working capital finance policy, are significant predictors of firm profitability.

Rehman et al. (2016) examined the impact of working capital management on profitability of firms in the Chemical Sector in Pakistan and reported that inventory turnover showed a significant impact on profitability, but did not see any significant impact for current ratio, acid test ratio and debtors' turnover ratio on firms' profitability

A positive significant relationship between profitability and current ratio and average collection period with a negative and insignificant relationship between profitability and inventory turnover in days was the outcome of a study by Iqbal, et al (2016) on 30 listed companies in Karachi Stock Exchange. A similar study by Zafar, Nazam, Hanif, Almas, and 
Sana, (2016), but on the Food Sector in Pakistan indicated a strong positive significant relationship between working capital management and firm's profitability.

Mahato, and Jagannathan (2016) compared Profitability (ROA) with working capital management components, debt and current ratios among eight listed telecom industry in India and the results revealed a negative relationship between profitability and inventory conversion period, average collection period, cash conversion cycle and current ratio, and a positive relationship of return on assets to average payment period, debt ratio and firm size.

An investigation by Mbawuni, Mbawuni, and Nimako, (2016) on the working capital management impact on profitability on five Petroleum retail firms in Ghana for the period 2008-2013 revealed that average payment period had a significant impact on profitability (ROA). It was also noted that the cash conversion cycle, average days of inventory and average day's receivables did not have any significant relationship with financial performance of selected firms.

Giri and Gyasuddin (2017) looked at the directional effect of working capital management and liquidity on profitability in the Petro Chemical industry in India for the period 2004-2014, and concluded that there was a bidirectional causal relationship between working capital management and profitability and a unidirectional causal relationship running from liquidity to profitability.

Maisiba, Muturi and Atambo (2017) looked at the effect of working capital management on profitability of 44 retail firms in Kenya and concluded that liquidity ratio, debt ratio and current ratio significantly influence profitability of selected retail firms.

A study on six listed manufacturing companies in Ghana by Tuffour, and Boateng (2017), reported that current ratio had significant impact on profitability, whereas inventory conversion period and cash conversion cycle had negative, but insignificant effect on financial performance. It was also noted that average collection period and accounts payable period had positive, but insignificant effect on profitability.

Nandom, Mubarik and Abdul-Aziz (2017) examined working capital and performance of non-financial firms in Ghana and found that average collection period, average payment period, cash conversion cycle and current ratio had a significant influence on firms' performance.

Kasozi (2017) examined the influence of working capital management on profitability among 69 listed manufacturing firms of Johannesburg Stock Exchange for the period 2007-16 and concluded that the average collection period and the average payment period significantly, but negatively influenced the financial performance of the listed firms. It was also observed that a positive and statistically significant relationship existed between the number of days in inventory and profitability.

\subsubsection{Other Parameters Used for Measurement of Profitability}

Deloof (2003) chose a sample of 1009 large Belgian non-financial firms to study the relationship between working capital management and profitability for the period 1992-1996. The study revealed a significant negative relationship between gross operating income and the number of days accounts receivable, inventories and accounts payable, which were consistent with the view that fewer profitable firms wait for a long a period of time to settle their outstanding bills. The results also suggested that managers could increase profitability by reducing the number of day's accounts receivable and inventories.

An investigation on working capital management and profitability was done by Lazaridis and Tryfonidis (2006) on a sample of 131 listed companies in Athens and noted significant relationship between profitability (gross operating profit) and the cash conversion cycle.

Gill, Biger, and Mathur (2010) tested a sample of 88 American firms listed on New York Stock exchange for a period of 3 years from 2005 to 2007 to find the relationship between working capital management and profitability. The test results indicated a significant relationship between cash conversion cycle and profitability, measured through gross operating profit.

The study by Vahid, Elham, Mohsen, and Mohammadreza, (2012) of 50 different Iranian firms listed in Tehran Stock Exchange for the period 2006-2009 indicated that there was a negative and significant relationship between the variables of average collection period, inventory turnover in days, average payment period, net trading cycle and the performance of the selected firms. In addition, no evidence was found to show the existence of a significant relationship between cash conversion cycle and the performance of the business (net operating profit). It also revealed the fact that the profitability would decrease on account of the increase in the collection period, payment period and in net trading.

Abuzayed (2012), analysed listed firms in Jordan for the period of 2002-2008 to measure the impact of working capital management on firms' profitability and noted that profitability is positively affected by the cash conversion cycle. 
Research carried out by Ray (2012) on the relationship between working capital management components and profitability of 311 Indian manufacturing firms for the period 1996-97 - 2009-10, revealed a strong negative relationship between average collection period, cash conversion cycle and debt ratio with corporate profitability. The study used average collection period, inventory turnover in days, average payment period, cash conversion cycle, current ratio, debt ratio, size of the firm and financial assets to total assets ratio to assess the impact of working capital management on profitability.

Ademola (2014), studied on working capital - profitability relationship among 120 food and beverages firms listed in Nigerian Stock Exchange for the period 2002-2011 and found insignificant relationship between cash conversion cycle and net operating profit, a significant negative relationship between accounts collection period and net operating profit and an insignificant negative relationship between inventory conversion period and accounts payment period to net operating profit.

Fahim, Kaviani, and Fashtali (2015), examined 90 listed companies on the Tehran Stock Exchange for the period 2008 -2012 to establish the relationship between working capital management and profitability and observed a significant inverse U-shape relationship of current ratio and quick ratio with Return on Assets, but did not see any significant inverse U-shape relationship of cash conversion cycle and net working capital to return on assets.

Jahfer (2015) investigated the effects of working capital management on profitability of manufacturing companies in Sri Lanka for the period 2008-2013. Findings indicated that there was a significant negative relationship between accounts payable and profitability and that managers could create value by reducing accounts receivable and net trading cycle and maintain reasonable inventory level. In addition, no evidence was found of a significant relationship between cash conversion cycle and profitability.

Garg and Gumbochuma (2015), studied the working capital management relationship with profitability among retail sector companies in South Africa listed in Johannesburg Stock Exchange for the period 2004-2013 and found a negative relationship between working capital and profitability. Debt ratio and financial performance was also found to be having a negative relationship. The leverage factor showed a statistically insignificant impact on profitability.

Louw (2015) examined 18 South African retail firms in the Johannesburg Stock Exchange for the period 2004-12 on their working capital management and its impact on financial performance. The results showed that South African firms reduce their cash conversion cycle by reducing their selling prices and/or cost prices, leading to increased profit.

Anarfi and Boateng (2016), used the average collected period, inventory turnover days, and average payment period as working capital management indicators along with cash conversion cycle to establish the effect of working capital management on profitability in the firms operating in the Czech Agriculture and Forestry sector for the period of 20052014. The results highlighted that indicators of working capital management do not affect profitability, but firm size, ratio of financial assets to total assets, leverage and current ratio significantly affect profitability.

A strong negative correlation between working capital management components and profitability was identified by Abbas and Yushan (2016), in their study on the effects on profitability of Tanzanian Insurance companies for the period 2006-2010.

Selecting a period of 15 years from 2000-2015, Dalayeen (2017), looked at the working capital management and profitability of selected real estate industry in Jordan and the findings showed significant influence of working capital management on the profitability of selected real estate companies.

The above review of literature indicates varied use of working capital management components to measure the impact of working capital management on corporate financial performance. Table 1 shows the variables used by various researchers in their studies. 
Table 1. Variables and their application in prior studies

\begin{tabular}{|c|c|}
\hline Variables & Authors and year of publication \\
\hline Return on Assets & $\begin{array}{l}\text { Kasozi (2017); Maisiba, Muturi and Atambo (2017); Nandom, Mubarik and Abdul-Aziz } \\
\text { (2017); Tuffour, and Boateng, (2017); Iqbal, Khan, Shah and Raza (2016); Mahato, and } \\
\text { Jagannathan (2016); Mbawuni, Mbawuni, and Nimako, (2016); Rehman, Khan, } \\
\text { Muhammad, Iqbal and Khan (2016); Temtime (2016); Zafar, Nazam, Hanif, Almas, and } \\
\text { Sana, (2016); Azeez (2015); Fahim, Kaviani, and Fashtali, (2015); Agha, (2014); } \\
\text { Odhiambo (2014); Makori and Jagongo (2013); Saghir, Hashmi, and Hussain, (2011) }\end{array}$ \\
\hline $\begin{array}{l}\text { Average Collection } \\
\text { Period }\end{array}$ & $\begin{array}{l}\text { 1 Dalayeen, (2017); Kasozi (2017); Tuffour, and Boateng, (2017); Nandom, Mubarik and } \\
\text { Abdul-Aziz (2017); Mahato, and Jagannathan (2016); Padachi (2006); Vahid, Elham, } \\
\text { Iqbal, Khan, Shah and Raza (2016); Rehman, Khan, Muhammad, Iqbal and Khan (2016); } \\
\text { Abbas and Yushan, (2016); Anarfi, and Boateng, (2016); Temtime (2016); Mbawuni, } \\
\text { Mbawuni, and Nimako, (2016); Azeez (2015); Jahfer (2015);Ademola, (2014); Agha, } \\
\text { (2014); Odhiambo (2014);Makori and Jagongo (2013); Saghir, Abuzayed, B. (2012); } \\
\text { Mohsen, and Mohammadreza, (2012); Ray (2012); Hashmi, and Hussain, (2011); Gill, } \\
\text { Biger, Mathur, (2010); Lazaridis and Tryfonidis, (2006) }\end{array}$ \\
\hline $\begin{array}{l}\text { Inventory } \\
\text { Conversion Period }\end{array}$ & $\begin{array}{l}\text { Kasozi (2017); l Dalayeen, (2017); Tuffour, and Boateng, (2017); Nandom, Mubarik and } \\
\text { Abdul-Aziz (2017);); Iqbal, Khan, Shah and Raza (2016); Rehman, Khan, Muhammad, } \\
\text { Iqbal and Khan (2016); Mahato, and Jagannathan (2016); Anarfi, and Boateng, (2016); } \\
\text { Temtime (2016); Mbawuni, Mbawuni, and Nimako, (2016); Jahfer (2015); Ademola, } \\
\text { (2014); Agha, (2014); Azeez (2015); Odhiambo (2014); Makori and Jagongo (2013); } \\
\text { Vahid, Elham, Mohsen, and Mohammadreza, (2012); Abuzayed, B. (2012); Ray ( 2012); } \\
\text { Saghir, Hashmi, and Hussain, (2011);); Gill, Biger, Mathur, (2010); Lazaridis and } \\
\text { Tryfonidis (2006); Padachi (2006) }\end{array}$ \\
\hline $\begin{array}{l}\text { Average Payment } \\
\text { Period }\end{array}$ & $\begin{array}{l}\text { Kasozi (2017); Nandom, Mubarik and Abdul-Aziz (2017); Tuffour, and Boateng, (2017); } \\
\text { Abbas and Yushan, (2016); Anarfi, and Boateng, (2016); Mahato, and Jagannathan (2016); } \\
\text { Mbawuni, Mbawuni, and Nimako, (2016); Temtime (2016); Jahfer (2015); Ademola, } \\
\text { (2014); Agha, (2014); Odhiambo (2014); Makori and Jagongo (2013); Vahid, Elham, } \\
\text { Mohsen, and Mohammadreza, (2012); Abuzayed, B. (2012); Ray (2012); Saghir, } \\
\text { Hashmi, and Hussain, (2011); Gill, Biger, Mathur, (2010); Padachi (2006); Lazaridis and } \\
\text { Tryfonidis (2006) }\end{array}$ \\
\hline $\begin{array}{l}\text { Cash Conversion } \\
\text { Cycle }\end{array}$ & $\begin{array}{l}\text { Kasozi (2017); Tuffour, and Boateng, (2017); Anarfi, and Boateng, (2016); Mbawuni, } \\
\text { Mbawuni, and Nimako, (2016); Mahato, and Jagannathan (2016); Temtime (2016); Garg, } \\
\text { and Gumbochuma, (2015); Jahfer (2015); Fahim, Kaviani, and Fashtali, (2015); Azeez } \\
\text { (2015); Ademola, (2014); Agha, (2014); Odhiambo (2014); Makori and Jagongo (2013); } \\
\text { Vahid, Elham, Mohsen, and Mohammadreza, (2012); Abuzayed, B. (2012); Ray (2012); } \\
\text { Saghir, Hashmi, and Hussain, (2011); Gill, Biger, Mathur, (2010); Padachi (2006); } \\
\text { Lazaridis and Tryfonidis (2006); }\end{array}$ \\
\hline Debt Ratio & $\begin{array}{l}\text { Maisiba, Muturi and Atambo (2017); Mahato, and Jagannathan (2016); Zafar, Nazam, } \\
\text { Hanif, Almas, and Sana, (2016); Anarfi, and Boateng, (2016); Garg, and Gumbochuma, } \\
\text { (2015); Odhiambo (2014); Ray (2012); Vahid, Elham, Mohsen, and Mohammadreza, } \\
\text { (2012); Gill, Biger, Mathur, (2010); Lazaridis and Tryfonidis (2006) }\end{array}$ \\
\hline Current Ratio & $\begin{array}{l}\text { 1 Dalayeen, (2017); Maisiba, Muturi and Atambo (2017); Tuffour, and Boateng, (2017); } \\
\text { Nandom, Mubarik and Abdul-Aziz (2017); Mahato, and Jagannathan (2016); Iqbal, Khan, } \\
\text { Shah and Raza (2016); Zafar, Nazam, Hanif, Almas, and Sana, (2016); Rehman, Khan, } \\
\text { Muhammad, Iqbal and Khan (2016); Abbas and Yushan, (2016); Anarfi, and Boateng, } \\
\text { (2016); Fahim, Kaviani, and Fashtali, (2015); Ademola, (2014); Agha, (2014); Makori and } \\
\text { Jagongo (2013); Vahid, Elham, Mohsen, and Mohammadreza, (2012); Ray (2012); }\end{array}$ \\
\hline Quick Ratio & $\begin{array}{l}\text { Maisiba, Muturi and Atambo (2017); Rehman, Khan, Muhammad, Iqbal and Khan (2016); } \\
\text { Fahim, Kaviani, and Fashtali, (2015) }\end{array}$ \\
\hline
\end{tabular}

\section{Methodology}

This paper explores the effect of working capital management on the profitability of listed retail stores in Botswana. The study has adopted a panel data methodology (2012-2016) and an analytical and descriptive research design.

Literature indicates that a number of working capital parameters are used to measure the effect of working capital management on firms' performance. The following model developed for the study takes into account the literature on working capital management and profitability. 
Table 2. Variables and their computation

\begin{tabular}{l|l|l}
\hline Variables & Abbreviation & Formula \\
\hline Dependent Variable & & \\
\hline Return on Assets & ROA & Profit before Interest and Tax/ Total Assets \\
\hline Independent Variables & & \\
\hline Average Collection Period & ACP & Accounts Receivable /Net (Credit) Sales *365 \\
\hline Inventory Conversion Period & ICP & Average Inventory/Cost of Goods Sold (Cost of Sales)*365 \\
\hline Average Payment Period & APP & Accounts Payable/ Net (Credit) Purchases * 365 \\
\hline Cash Conversion Cycle & CCC & ACP+ICP-APP \\
\hline Debt Ratio & DR & Total Liabilities/Total Assets \\
\hline Current Ratio & CR & Current Assets/Current Liabilities \\
\hline Quick Ratio & QR & Current Assets less Closing Inventory/ Current Liabilities \\
\hline
\end{tabular}

\subsection{Variables}

\subsubsection{Dependent Variable:Return on Assets (ROA)}

Return on Assets which is a profitability ratio that measures the net income generated by total assets during a period is widely considered as the one of the most reliable measure of profitability. A number of researchers have used Return on Assets to find the impact of working capital management on profitability. Return on Assets is one of the central ratios defined by Selling and Stickney (1989) as 'a useful measure for evaluating the operating and investing performance of a firm.' These authors however argue that the behavior of this ratio is impacted upon by the macroeconomic and business strategies of the firm. They, of course, indicate that the ratio naturally varies 'over time and across firms and industries'. Selling and Stickney's key argument is that the firm's environment and how strategies adopted to in response to that environment should be considered in understanding the behavior of ROA. They also concluded in their study that: '... industries with significant operating leverage and high entry barriers tended to have the lowest asset turnovers and the highest profit margins, while industries with low capital intensity and commodity-like products tended to have the highest asset turnovers and the lowest profit margins.' p. 43

\subsubsection{Independent Variables}

1. Average Collection period (ACP): It is a significant component of working capital management that determines the cash flows of a firm. It is the period from the date the credit facility is extended to when the actual payment is received.

The management of this ratio is critical for the firm's ability to meet its own obligations.

2. Inventory Conversion period (ICP): The Inventory conversion period is the time the firm takes to convert inventory into sales. This ratio therefore measures the time from acquisition of inventory to its sale. The longer the inventory remains in the shelves, the longer the time to acquire cash. This is problematic because sales here might also be on credit and this further pushes the cash realization further.

3. Average Payment Period (APP): Average payment period is the average time it takes for a firm to pay its creditors. A shorter payment period is preferred if it attracts discounts, otherwise the full length of the credit facility provided by the supplier should be taken advantage of.

4. Cash Conversion Cycle (CCC): The cash conversion cycle is considered a more effective measure of liquidity than the traditional assessments such as current and quick ratio (Moss and Stine, 1993; Almamy., Aston \& Ngwa, 2016). Moss and Stine suggests that the current and quick ratios are static values. CCC is considered more versatile in its ability to measure to cover obligation because it also indicates the ability of the firm to manage its cash. Here levels of cash are important to avoid excessive cash balances or lack of it. Moss and Stine observed that the CCC is the focal point of other working capital ratios such as inventory conversion period and receivables conversion period.

5. Debt Ratio (DR): Debt ratio is generally considered as a measure of debt level of a firm against its assets. The level of debt against assets helps assess whether it is sustainable to continue with debt financing. Higher levels of debt can actually cripple the firms operations given the type of environment especially where interest is high, and banks are not an intrinsic part of the business. A lower debt level may also indicate that the firm is not effectively using a financing facility that may improve growth. The question of whether an optimal debt ratio exists remains a significant point for debate (Smyth \&Hsing, 1995; Chudik., Mohaddes., Pesaran \& Raissi, 2017).

6. Current Ratio: Current ratio is a traditional measure of a firm's ability to pay off its short-term obligations. The complexity in contemporary business is that a higher current ratio suggests inability to effectively utilize cash for investment whilst a lower current ratio is perceived as risky, leaving a firm susceptible to defaulting (Richards \& Laughlin, 1980; Dambolena \& Khoury,1980). 
7. Quick Ratio: Quick ratio measures the firm's ability to settle its short-term obligations using assets that are readily convertible into cash, i.e. excluding inventories. Inventory may take longer to convert into cash hence it is excluded.

\subsection{Conceptual Frame Work}

The following diagram indicates the independent variables and dependent variable used in the study to measure the impact of the independent variables of average collection period, inventory conversion period, average payment period, cash conversion cycle, debt ratio, current ratio and quick ratio on the dependent variable Return on Assets of the listed retail stores in Botswana.

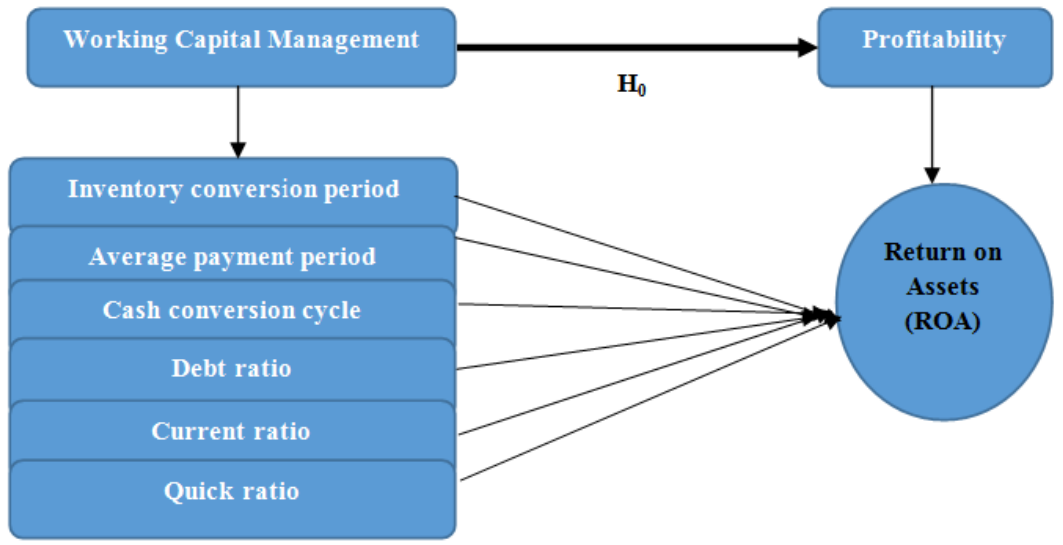

Figure 1. Diagram of Independent \& Dependent variables

\subsection{Data Source and Sampling}

The research population for the study are all the listed retail stores in Botswana. The study used non-probability sampling (purposive sampling) where a pre-specified group are purposively pursued and tested. The data was obtained from the annual reports of the three listed retail stores on Botswana Stock Exchange (BSE) for the period 2012-2016.

\subsection{Model for Data Analysis}

This data included the dependent variable being Return on Assets (ROA) and the independent variables being seven components generally used to measure working capital management, that is, average collection period, inventory conversion period, average payment period, cash conversion cycle, debt ratio, current ratio and quick ratio. The relationship is mathematically expressed in equation 1 ;

$$
\mathrm{ROA}_{\mathrm{t}}=\beta_{0}+\beta_{1} \mathrm{ACP}_{\mathrm{t}}+\beta_{2} \mathrm{ICP}_{\mathrm{t}}+\beta_{3} \mathrm{APP}_{\mathrm{t}}+\beta_{4} \mathrm{CCC}_{\mathrm{t}}+\beta_{5} \mathrm{DR}_{\mathrm{t}}+\beta_{6} \mathrm{CR}_{\mathrm{t}}+\beta_{7} \mathrm{QR}_{\mathrm{t}}+\varepsilon_{\mathrm{t}}
$$

Where;

$$
\begin{aligned}
& \mathrm{ROA}_{\mathrm{t}}=\text { Return on Assets } \\
& \mathrm{ACP}=\text { Average collection period } \\
& \mathrm{ICP}=\text { Inventory conversion period } \\
& \mathrm{APP}=\text { Average payment period } \\
& \mathrm{CCC}=\text { Cash conversion cycle } \\
& \mathrm{DR}=\text { Debt ratio } \\
& \mathrm{CR}=\text { Current ratio } \\
& \mathrm{QR}=\text { Quick ratio } \\
& \beta_{0,} \beta_{1}, \beta_{\mathrm{n}}=\text { Coefficients } \\
& \varepsilon_{\mathrm{t}}=\text { error term }
\end{aligned}
$$

\section{Data Analysis and Discussion of Findings}

The central hypothesis of the study states that there is no statistically significant association between working capital management and firm profitability. A review of prior studies confirmed that correlation and regression analysis techniques are found most appropriate to establish relationship between working capital management and financial performance of business enterprises. The data of this study, therefore, was analysed using descriptive statistics, correlation analysis and regression analysis. The data covers a 5- year period from 2012 to 2016. Statistical Package for Social Sciences (SPSS) was used to carry out the analysis. 


\subsection{Descriptive Statistics}

Descriptive statistics generated through SPSS are shown in Table 3. The dataset is comprised of 15 observations. The dependent variable is measured by Return on Assets (ROA). ROA measures the effectiveness of management in terms of use of assets. The ROA has a minimum value of 0.045 and a maximum of 0.184 . Meanwhile the mean return is 0.118 . This shows that on average, the three retail stores generated a return on assets of around $11.8 \%$. On the other hand, the independent variables are the measures of working capital management and they include; the average collection period (ACP), inventory conversion period (ICP), Average payment period (APP), Cash conversion cycle(CCC),Debt ratio (DR), Current ratio(CR) and quick ratio (QR). The ACP had a mean of 11.060 days and standard deviation of 5.538. The maximum and minimum values were 19.855 and 3.113 days respectively. On the other hand, the ICP, which measures how quickly the company is able to turn raw material into finished goods, had a mean value of 75.505 days. The maximum value was 155.821 days with a minimum value of 29.729 days. Meanwhile the APP stood at an average value of 46.597 days and was skewed to the right (skewness $=0.5$ ), with a maximum value of 84.877 days. In contrast, the CCC had a mean value of 39.988, with a maximum of 106.648 and a minimum value of -7.030 . The DR had a mean value of 0.503 and a standard deviation of 0.0044 . Lastly, the liquidity ratios of CR and QR has a mean (standard deviation) of 2.3686 (1.5150 and 1.582 (1.274) respectively.

Table 3. Descriptive Statistics

\begin{tabular}{|c|c|c|c|c|c|c|c|c|c|}
\hline & $\mathbf{N}$ & Minimum & Maximum & Mean & Std. Deviation & Skewnes & & Kurtosis & \\
\hline & Statistic & Statistic & Statistic & Statistic & Statistic & Statistic & Std. Error & Statistic & Std. Error \\
\hline ROA & 15 & 0.045 & 0.184 & 0.118 & 0.035 & -0.248 & 0.58 & 0.352 & 1.121 \\
\hline ACP & 15 & 3.113 & 19.855 & 11.060 & 5.538 & 0.398 & 0.58 & -1 & 1.121 \\
\hline ICP & 15 & 29.729 & 155.821 & 75.505 & 53.130 & 0.778 & 0.58 & -1.552 & 1.121 \\
\hline APP & 15 & 14.112 & 84.877 & 46.597 & 15.460 & 0.500 & 0.58 & 2.662 & 1.121 \\
\hline CCC & 15 & -7.030 & 106.648 & 39.968 & 42.982 & 0.568 & 0.58 & -1.553 & 1.121 \\
\hline DR & 15 & 0.361 & 0.503 & 0.412 & 0.044 & 0.854 & 0.58 & -0.249 & 1.121 \\
\hline CR & 15 & 1.030 & 5.431 & 2.386 & 1.515 & 1.278 & 0.58 & 0.107 & 1.121 \\
\hline QR & 15 & 0.388 & 4.028 & 1.582 & 1.274 & 1.149 & 0.58 & -0.289 & 1.121 \\
\hline
\end{tabular}

3.2 Correlation Analysis

In order to confirm whether the variables are not highly correlated with each other (multicollinearity), Pearson correlation was performed on SPSS and the results are shown in Table 4. Most of the variables were not significantly correlated with each other. APP and ICP were positively and significantly correlated with each other at $10 \%$ significant level $(\mathrm{p}=0.683)$. Further analysis indicates that $\mathrm{CCC}$ is significantly and positively correlated with ICP $(\mathrm{p}=0.957)$ which is one of its components. This shows that a 1 unit increase in ICP will increase CCC by 0.957 . This makes sense because theoretically if inventory conversion increases, CCC should increase; all other components held constant. On the other hand, CR is found to be significantly and positively correlated with ICP and CCC at $10 \%$ level with $\mathrm{p}$ values of 0.860 and 0.842 respectively. Meanwhile, the QR was found to be positively and significantly correlated with ICP, CCC and CR at 10\% level and with APP at 5\% level. Since majority of the variables were not highly and significantly correlated with each other, multicollinearity was found not to be of a problem. The only two variables which were significantly correlated with four or more variables were ICP and QR. We therefore proceeded with regression analysis.

Table 4. Pearson correlation

\begin{tabular}{|c|c|c|c|c|c|c|c|c|c|}
\hline ROA & $\begin{array}{l}\text { Pearson Correlation } \\
\text { Sig. (2-tailed) }\end{array}$ & $\begin{array}{l}\text { ROA } \\
1\end{array}$ & ACP & ICP & APP & $\mathrm{CCC}$ & DR & CR & QR \\
\hline $\mathrm{ACP}$ & $\begin{array}{l}\text { Pearson Correlation } \\
\text { Sig. (2-tailed) }\end{array}$ & $\begin{array}{l}0.025 \\
0.928\end{array}$ & 1 & & & & & & \\
\hline ICP & $\begin{array}{l}\text { Pearson Correlation } \\
\text { Sig. (2-tailed) }\end{array}$ & $\begin{array}{l}0.018 \\
0.948\end{array}$ & $\begin{array}{l}-0.258 \\
0.354\end{array}$ & 1 & & & & & \\
\hline APP & $\begin{array}{l}\text { Pearson Correlation } \\
\text { Sig. (2-tailed) }\end{array}$ & $\begin{array}{l}0.195 \\
0.487\end{array}$ & $\begin{array}{l}-0.164 \\
0.559\end{array}$ & $\begin{array}{l}.683 * * \\
0.005\end{array}$ & 1 & & & & \\
\hline $\mathrm{CCC}$ & $\begin{array}{l}\text { Pearson Correlation } \\
\text { Sig. (2-tailed) }\end{array}$ & $\begin{array}{l}-0.044 \\
0.876\end{array}$ & $\begin{array}{l}-0.131 \\
0.643\end{array}$ & $\begin{array}{l}.957 * * \\
0\end{array}$ & $\begin{array}{l}0.463 \\
0.082\end{array}$ & 1 & & & \\
\hline DR & $\begin{array}{l}\text { Pearson Correlation } \\
\text { Sig. (2-tailed) }\end{array}$ & $\begin{array}{l}-0.291 \\
0.292\end{array}$ & $\begin{array}{l}-0.292 \\
0.291\end{array}$ & $\begin{array}{l}-0.351 \\
0.2\end{array}$ & $\begin{array}{l}-0.169 \\
0.546\end{array}$ & $\begin{array}{l}-0.41 \\
0.129\end{array}$ & 1 & & \\
\hline CR & $\begin{array}{l}\text { Pearson Correlation } \\
\text { Sig. (2-tailed) }\end{array}$ & $\begin{array}{l}-0.256 \\
0.356\end{array}$ & $\begin{array}{l}-0.284 \\
0.305\end{array}$ & $\begin{array}{l}.860 * * \\
0\end{array}$ & $\begin{array}{l}0.513 \\
0.051\end{array}$ & $\begin{array}{l}.842 * * \\
0\end{array}$ & $\begin{array}{l}-0.33 \\
0.23\end{array}$ & 1 & \\
\hline QR & $\begin{array}{l}\text { Pearson Correlation } \\
\text { Sig. (2-tailed) }\end{array}$ & $\begin{array}{l}-0.18 \\
0.52\end{array}$ & $\begin{array}{l}-0.279 \\
0.314\end{array}$ & $\begin{array}{l}.888 * * \\
0\end{array}$ & $\begin{array}{l}.576^{*} \\
0.025\end{array}$ & $\begin{array}{l}.855^{* *} \\
0\end{array}$ & $\begin{array}{l}-0.353 \\
0.197\end{array}$ & $\begin{array}{l}.995^{* *} \\
0\end{array}$ & 1 \\
\hline
\end{tabular}

**. Correlation is significant at the 0.01 level (2-tailed). 
*. Correlation is significant at the 0.05 level (2-tailed).

\subsection{Regression Analysis}

A multiple regression analysis was performed to test the significance of the relationship between profitability measured by return on assets (ROA) as a dependent variable and the seven working capital management components as independent variables. The model was first tested for goodness of fit using the r-squared value which retained a value of 0.903 . This outcome shows that $90.3 \%$ of the variation in ROA can be explained by the seven independent variables. The regression output is shown in Table 5. SPSS dropped ICP automatically as it was significantly correlated with CCC as one of the components.The regression output shows that only three variables out of the remaining six were significant, namely APP, CR and QR (p-value $<0.05)$.

First, profitability as measured by ROA is found to be negatively and significantly related with average payment period (APP) with a p-value of 0.009, which confirms the findings of Kasozi (2017) who examined the influence of working capital management on profitability among 69 listed manufacturing firms of Johannesburg stock exchange for the period 2007-16. Kasozi (2017) concluded that the average collection period and the average payment period were significantly, but negatively influenced the financial performance of the listed firms. However, our outcome is contrary to the findings of Mahato, and Jagannathan (2016) and Mbawuni, Mbawuni, and Nimako, (2016) who found a positive relationship. The beta coefficient associated with this variable in Table 5 is -0.02 . This shows that a $1 \%$ increase in ACP will reduce profitability as measured by return on assets by $0.0002 \%$. Though the magnitude of this impact is small, it is found to be significant ( $\mathrm{p}$ value $=0.009$ ).

Secondly, a negative and significant relationship was found between the return on assets and current ratio (CR) $(\mathrm{p}=0.000)$. This outcome confirms the findings of Fahim, Kaviani, and Fashtali, (2015) and Mahato, and Jagannathan (2016) who observed a significant negative relationship between the two variables. However a current study by Rehman et al. (2016) who examined the impact of working capital management on profitability of firms in the Chemical sector in Pakistan reported that inventory turnover showed a significant impact on profitability, but did not see any significant impact for current ratio. In contrast, the current ratio was found to significantly influence profitability in other latest studies (Iqbal, et al, 2016; Maisiba, Muturi and Atambo, 2017; Tuffour, and Boateng, 2017; Nandom, Mubarik and Abdul-Aziz, 2017). Likewise, the beta coefficient associated with this regression model as presented in Table 5 is -0.332. In this respect, a $1 \%$ increase in CR will reduce profitability as measured by return on assets by $0.03 \%$.

Thirdly, a positive and significant relationship is found between return on assets and quick ratio or acid test $(\mathrm{p}=0.000)$. This outcome is contrary to the findings of Fahim, Kaviani, and Fashtali, (2015) who examined 90 listed companies on the Tehran stock exchange for the period 2008 -2012 in order to establish the relationship between working capital management and profitability and observed a significant inverse U-shape relationship of quick ratio with Return on Assets. Meanwhile, Rehman et al. (2016) did not see any significant impact for current ratio, acid test ratio and debtors' turnover ratio on firms' profitability in Pakistan. The beta coefficient of the regression model is 0.402 , which shows that a $1 \%$ increase in quick ratio will increase profitability by $0.004 \%$.

Table 5. Regression Output

\begin{tabular}{|c|c|c|c|c|c|c|}
\hline \multicolumn{2}{|c|}{ Model } & \multicolumn{2}{|c|}{ Unstandardized Coefficients } & \multirow{2}{*}{$\begin{array}{c}\begin{array}{c}\text { Standardized } \\
\text { Coefficients }\end{array} \\
\text { Beta } \\
\end{array}$} & \multirow[t]{2}{*}{$\mathrm{t}$} & \multirow{2}{*}{$\begin{array}{l}\text { Sig. or } \\
\text { p-value }\end{array}$} \\
\hline & & $\mathrm{B}$ & Std. Error & & & \\
\hline \multirow[t]{7}{*}{1} & (Constant) & .409 & .055 & & 7.435 & .000 \\
\hline & ACP & -.001 & .001 & -.148 & -1.134 & .290 \\
\hline & APP & -.002 & .001 & -.872 & -3.460 & .009 \\
\hline & $\mathrm{CCC}$ & .000 & .000 & -.129 & -.553 & .595 \\
\hline & DR & -.074 & .117 & -.093 & -.634 & .544 \\
\hline & CR & -.332 & .052 & -14.448 & -6.394 & .000 \\
\hline & QR & .402 & .068 & 14.741 & 5.945 & .000 \\
\hline
\end{tabular}

a. Dependent Variable: ROA

\subsection{Summary of Findings}

A total of seven working capital items were identified from literature as independent variables and these were comprised of average collection period, inventory conversion period, average payment period, cash conversion cycle, debt, current and quick ratios. Correlation analysis revealed that few variables were significantly correlated with each other. In particular, APP and ICP were found to be positively and significantly correlated with each other at $10 \%$ significant level, CCC was significantly and positively correlated with ICP;CR is found to be significantly and positively correlated with ICP and CCC at $10 \%$ level, and QR was found to be positively and significantly correlated with ICP, CCC and CR at $10 \%$ level and with APP at 5\% level. A multiple regression analysis was also performed and 
the results showed that only three variables out of the seven independent variables were significant, namely APP, CR and QR. The remaining four variables were found to be statistically insignificant. Profitability as measured by return on assets was found to be negatively and significantly related to average payment period (APP), a negative and significant relationship was found between return on assets and current ratio, and a positive and significant relationship is found between return on assets and quick ratio. Overall, the findings indicated that there was no significant relationship between independent variables "average collection period, inventory conversion period, cash conversion cycle, debt ratio" and the dependent variable " return on assets" leading to the acceptance of null hypothesis for the above-mentioned variables. The hypothetical testing, however, rejected the null hypothesis on the relationship between independent variables "average payment period, current ratio, quick ratio" and the dependent variable "return on assets".

\section{Conclusion and Recommendations}

The importance of working capital management as an essential component of financial management originates from the fact that investment in current asset constitutes a significant part of total investment of a business enterprise. As a result, this study sought to establish the impact of working capital management on the financial performance of listed retail stores in Botswana.

The above findings have implications for management of the retail stores in Botswana. In particular, management should pay more attention to APP, CR and QR if they want to improve profitability of their firms. Working capital management deals with management of current assets and current liabilities and monitoring the inter-relationship between them. It aims to manage both current assets and current liabilities in such a way that a satisfactory level is maintained. Poor management of working capital may lead to business collapse resulting from insolvency.

Since a negative relationship is found between average payment period and the return on assets, management should devise ways of ensuring that they reduce the average payment period in order to improve profitability of their firms. This could include negotiating better credit terms with suppliers which could include not delaying payments to suppliers unnecessarily. In terms of the current ratio, a negative relationship is also found. In this respect, management should ensure that they reduce the current ratio by minimizing their current asset levels in order to stimulate profitability. In contrast, the quick ratio showed a positive and significant relationship with return on assets, which confirms that management should increase their most liquid assets if they want to improve their profitability. In this case, they should increase their holdings of cash and cash equivalents, securities and receivables. In retrospect, fewer inventories should be held at all times in order to improve profitability of retails stores in Botswana. Therefore better inventory handling techniques should be put in place such as consistently reducing lead times and putting in place better Management Resource Planning techniques.

The study focused on the three listed retail stores for the period 2012-16. A future study with extended dataset on the above components might help to assess in more detail the relationship between profitability and working capital management. The current dataset was constrained by data on one of the retails stores which was only listed about five years ago. Also, a much larger sample size by including all the listed firms in the consumer services sector may improve the relevance of the findings. Despite the aforementioned limitations, the study provides an in depth understanding of the impact of working capital management on the financial performance of listed retail stores in Botswana.

\section{References}

Abbas, A. O., \& Yushan, C. (2016). Does Effective Working Capital Management Increase Profitability? Evidence: Tanzania Insurance Company. Journal of Accounting and Financial Management, 2(4), 12-20.

Abosede, S. A., \& Luqman, O. S. (2014). A Comparative Analysis on Working Capital Management of Brewery Companies in Nigeria. International Journal of Finance and Accounting, 3(6), 356-371. https://doi.org/10.2139/ssrn.2514668

Abuzayed, B. (2012). Working Capital Management and Firms' Performance in Emerging Markets: The Case of Jordan. International Journal of Managerial Finance, 8(2), 155-179. https://doi.org/10.1108/17439131211216620

Ademola, O. J. (2014). Working Capital Management and Profitability of Selected Quoted Food and Beverages Manufacturing Firms in Nigeria. European Journal of Accounting Auditing and Finance Research, 2(3), 10-21.

Agha, H. (2014). Impact of Working Capital Management on Profitability. European Scientific Journal, ESJ, 10(1).

Almamy, J., Aston, J., \& Ngwa, L. N. (2016). An Evaluation of Altman's Z-score using Cash Flow Ratio to Predict Corporate Failure Amid the Recent Financial Crisis: Evidence from the UK. Journal of Corporate Finance, 36, 278-285. https://doi.org/10.1016/j.jcorpfin.2015.12.009

Altman, E. I. (1968). Financial Ratios: Discriminant Analysis and the Prediction of Corporate Bankruptcy. The Journal of Finance, 23(4), 589-609. https://doi.org/10.1111/j.1540-6261.1968.tb00843.x 
Anarfi, D., \& Boateng, K. A. (2016). The Relationship between Working Capital Management and Profitability: Evidence from the Czech Agric and Forest Industry. Researchers World, 7(3), 109.

Azeez, N. O. (2015). Working Capital Management and Firms Performance: A Study of Manufacturing Companies in Nigeria (Doctoral dissertation). University of Nigeria, Enugu Campus, Nigeria.

Azeez, O. T., Abubakar, M. A., \& Olamide, F. T. (2016). Analysis of the Effects of Working Capital Management on Profitability of Listed Nigerian Conglomerate Companies. FWU Journal of Social Sciences, 10(1), 10.

Beaver, W. H. (1966). Financial Ratios as Predictors of Failure. Journal of accounting research, 71-111. https://doi.org/10.2307/2490171

Chudik, A., Mohaddes, K., Pesaran, M. H., \& Raissi, M. (2017). Is there a Debt-threshold Effect on Output Growth?. Review of Economics and Statistics, 99(1), 135-150. https://doi.org/10.1162/REST_a_00593

Dambolena, I. G., \& Khoury, S. J. (1980). Ratio Stability and Corporate Failure. The Journal of Finance, 35(4), 1017-1026. https://doi.org/10.1111/j.1540-6261.1980.tb03517.x

Deloof, M. (2003). Does Working Capital Management affect Profitability of Belgian Firms? Journal of business finance \& Accounting, 30(3 - 4), 573-588. https://doi.org/10.1111/1468-5957.00008

Fahim, S. R. S., Kaviani, M., \& Fashtali, M. P. (2015). Providing a New Model for Assessment of Working Capital Management: Evidence from Tehran Stock Exchange. International Journal of Accounting and Financial Reporting, 5(1), 108-122. https://doi.org/10.5296/ijafr.v5i1.7284

Garg, A. K., \& Gumbochuma, M. I. (2015). Relationship between Working Capital Management and Profitability in JSE Listed Retail Sector Companies. Investment Management and Financial Innovations, 12(2), 127-135.

Gill, A. (2011). Factors that Influence Working Capital Requirements in Canada. Economics and Finance Review, 1(3), $30-40$.

Gill, A., Biger, N., \& Mathur, N. (2010). The Relationship between Working Capital Management and Profitability: Evidence from the United States. Business and Economics Journal, 10(1), 1-9.

Iqbal, M., Khan, S., Shah, S. Q., \& Raza, W. (2016). Relationship between Working Capital Management and Profitability. International Journal for Innovative Research in Multidisciplinary Field, 2(8), 180-184.

Jahfer, A. (2015). Effects of Working Capital Management on Firm Profitability: Empirical Evidence from Sri Lanka. International Journal of Managerial and Financial Accounting, 7(1), 26-37. https://doi.org/10.1504/IJMFA.2015.067498

Kasozi, J. (2017). The Effect of Working Capital Management on Profitability: A Case of Listed Manufacturing Firms in South Africa. Investment Management and Financial Innovations, 14(2), 336-346. https://doi.org/10.21511/imfi.14(2-2).2017.05

Kumari, N. N., \& Anthuvan, M. V. L. (2017). A Study on The Impact of The Working Capital Management on The Profitability of The Leading Listed Automobile Companies In India. International Journal of Scientific Research and Management, 5(8), 6744-6757

Lazaridis, I., \& Tryfonidis, D. (2006).Relationship between Working Capital Management and Profitability of Listed Companies in the Athens Stock Exchange. Journal of Financial Management and Analysis, 19(1), 1-12.

1Dalayeen, B. (2017). Working Capital Management and Profitability of Real Estate Industry in Jordan: An Empirical Study. Journal of Applied Finance and Banking, 7(2), 49.

Louw, E. (2015). Management of working capital by listed South African retail companies (Doctoral dissertation, University of Pretoria).

Mahato, J., \& Jagannathan, U. K. (2016). Impact of Working Capital Management on Profitability: Indian Telecom Sector. J. of Management \& Commerce, 2(2), 17-23.

Maisiba, L. N., Muturi, W., \& Atambo, W. (2017) Effects of Working Capital Management on Profitability of Retail Firms in Kisii County, Kenya. International Journal of Social Sciences and Information Technology, 3(2), 1640-1655.

Makori, D. M., \& Jagongo, A. (2013). Working Capital Management and Firm Profitability: Empirical Evidence from Manufacturing and Construction Firms Listed on Nairobi Securities Exchange, Kenya. International Journal of Accounting and Taxation, 1(1), 1-14.

Mbawuni, J., Mbawuni, M. H., \& Nimako, S. G. (2016). The Impact of Working Capital Management on Profitability of Petroleum Retail Firms: Empirical Evidence from Ghana. International Journal of Economics and Finance, 8(6), 
49. https://doi.org/10.5539/ijef.v8n6p49

Moss, J. D., \& Stine, B. (1993).Cash Conversion Cycle and Firm Size: A study of Retail Firms. Managerial Finance, 19(8), 25-34. https://doi.org/10.1108/eb013739

Nandom, Y. I., Mubarik, A. M., \& Abdul, A. F. (2017). The Impact of Working Capital Management on Corporate Performance: Evidence from listed non-financial firms in Ghana. European Journal of Accounting, Auditing and Finance Research, 5(3), 68-75.

Odhiambo, O. B. (2014). The Effect of Working Capital Management and Profitability of Retail Stores in Migori County-Kenya.(Masters Dissertation) University of Nairobi, Kenya.

Ohlson, J. A. (1980). Financial Ratios and the Probabilistic Prediction of Bankruptcy, Journal of accounting research, 109-13. https://doi.org/10.2307/2490395

Padachi, K. (2006). Trends in Working Capital Management and its Impact on Firms' Performance: An Analysis of Mauritian Small Manufacturing Firms. International Review of business research papers, 2(2), 45-58.

Ray, S. (2012). Evaluating the Impact of Working Capital Management Components on Corporate Profitability: Evidence from Indian Manufacturing Firms. International Journal of Economic Practices and Theories, 2(3), 127-136.

Rehman, A., Khan, S., Muhammad, M., Iqbal, M., \& Khan, F. U. (2016). Impact of Working Capital Management on Firms' Profitability Evidence from Chemical Sector of Pakistan. Journal of International Academic Research for Multidisciplinary, 4(9), 138-152.

Richards, V. D., \& Laughlin, E. J. (1980). A Cash Conversion Cycle Approach to Liquidity Analysis. Financial management, 32-38.https://doi.org/10.2307/3665310

Saghir, A., Hashmi, F. M., \& Hussain, M. N. (2011). Working Capital Management and Profitability: Evidence from Pakistan Firms. Interdisciplinary Journal of Contemporary Research in Business, 3(8), 1092-1105.

Selling, T. I., \& Stickney, C. P. (1989).The Effects of Business Environment and Strategy on a Firm's Rate of Return on Assets.Financial Analysts Journal, 45(1), 43-52. https://doi.org/10.2469/faj.v45.n1.43

Smyth, D. J., \& Hsing, Y. (1995). In Search of an Optimal Debt Ratio for Economic Growth. Contemporary Economic Policy, 13(4), 51-59.https://doi.org/10.1111/j.1465-7287.1995.tb00731.x

Temtime, Z. T. (2016). Relationship between Working Capital Management, Policies, and Profitability of Small Manufacturing Firms (Doctoral dissertation, Walden University).

Tuffour, J. K., \& Boateng, J. A. (2017). Is Working Capital Management Important? Empirical Evidence from Manufacturing Companies in Ghana. Review of Innovation and Competitiveness: A Journal of Economic and Social Research, 3(1), 5-20.

Vahid, T. K., Elham, G., Mohsen, A., \& Mohammadreza, E. (2012). Working Capital Management and Corporate Performance: Evidence from Iranian Companies. Procedia-Social and Behavioural Sciences, 62, 1313-1318. https://doi.org/10.1016/j.sbspro.2012.09.225

Windaus. (2014). Cash for Growth PwC Annual Global Working Capital Survey. Retrieved on 5 December 2017 from http://www.pwc.com/gx/en/financial-services/publications/assets/working-capital-2014.pdf

Windaus. (2017). PwC Working Capital Report, 2017/18. Pressure in the system: Unlocking enterprise value through working capital management retrieved on 5 December 2017 from https://www.pwc.com/gx/en/services/advisory/deals/business-recovery-restructuring/working-capital-opportunity.h tml

Zafar, S., Nazam, M., Hanif, A., Almas, I., \& Sana, N. (2016). Impact of Working Capital Management on Firm's Profitability: A Case from Food Sector of Pakistan. European Journal of Accounting, Auditing and Finance Research, 4(10), 48-58.

\section{Copyrights}

Copyright for this article is retained by the author(s), with first publication rights granted to the journal.

This is an open-access article distributed under the terms and conditions of the Creative Commons Attribution license which permits unrestricted use, distribution, and reproduction in any medium, provided the original work is properly cited. 